\title{
Detection of a wide range of medically important fungi by the polymerase chain reaction
}

\author{
K. MAKIMURA*, SOMAY Y. MURAYAMA* and H. YAMAGUCHI* $\dagger$ \\ *Department of Microbiology and Immunology, Teikyo University School of Medicine, 2-11-1 Kaga, Itabashi-ku, \\ Tokyo 173 and + Research Center for Medical Mycology, Teikyo University, 359 Ohtsuka, Hachioji, Tokyo 192-03, \\ Japan
}

\begin{abstract}
Summary. A polymerase chain reaction (PCR) method was developed that was capable of detecting a wide range of medically important fungi from clinical specimens. The primer pair was designed in conserved sequences of 18S-ribosomal RNA genes shared by most fungi. The lower limit of detection of this PCR technique was $1 \mathrm{pg}$ of Candida albicans genomic DNA by ethidium bromide staining and $100 \mathrm{fg}$ after Southern analysis. A 687-bp product was amplified successfully by PCR from all 78 strains of 25 medically important fungal species studied, including Candida spp., Hansenula spp., Saccharomyces cerevisiae, Cryptococcus neoformans, Trichosporon beigelii, Malassezia furfur, Pneumocystis carinii, Aspergillus spp., and Penicillium spp., but not from any strains of Mucor spp., Escherichia coli, or methicillinresistant Staphylococcus aureus (MRSA), calf thymus or human placenta. This specificity was subsequently confirmed by Southern analysis. PCR analysis of blood specimens collected from mice systemically infected with $C$. albicans and clinical samples including blood, cerebrospinal fluid and sputum appeared to be a more sensitive diagnostic method for invasive fungal infections than a conventional blood culture technique.
\end{abstract}

\section{Introduction}

Invasive candidosis, aspergillosis and other lifethreatening fungal infections occur increasingly frequently in immunocompromised patients. Furthermore, the variety of causative agents is expanding..$^{1-3}$ These factors make laboratory diagnosis by conventional culture methods more difficult and time-consuming. Serodiagnostic kits have been developed for early diagnosis, but some of these have problems in sensitivity or specificity, or both, even though they are rapid to perform. ${ }^{4-6}$

To improve the sensitivity and specificity of detection of pathogenic fungi, molecular biological methods have been developed recently. Some laboratory diagnostic methods with Southern hybridisation have been reported. Gabal ${ }^{7}$ detected A. fumigatus DNA in an amount equivalent to 3 cfu with a total Aspergillus fumigatus chromosomal DNA probe ${ }^{1}$. Holmes et al. ${ }^{8}$ reported that Candida albicans specific repetitive sequence was detectable from human blood specimens that contained $\geqslant 500$ yeast cells $/ \mathrm{ml}$. DNA probes for ribosomal RNA (rRNA) of several species of pathogenic fungi are now available commercially. ${ }^{9}$

The polymerase chain reaction $\left(\mathrm{PCR}^{10}\right)$ is the most sensitive and specific technique of detecting a specific

Received 30 Sept. 1993; revised version accepted 16 Nov. 1993.
DNA sequence, and species-specific PCR-diagnostic methods applicable to $C$. albicans, A. fumigatus or Pneumocystis carinii are available. ${ }^{11-20}$ These PCR techniques are capable of detecting $>1 \mathrm{pg}$ of fungal genomic DNA or one-to-15 fungal cells with great accuracy.

The increasing incidence of invasive fungal infections caused by uncommon fungi including nonalbicans Candida spp., Hansenula spp., Saccharomyces cerevisiae, Trichosporon beigelii, Malassezia furfur and Penicillium spp., in immunocompromised hosts ${ }^{1-3,21,22}$ has made it essential to have a means of identifying a broad variety of medically important fungi. Hopfer $e t$ $a l .{ }^{23}$ reported a PCR method with a previously described primer system ${ }^{24}$ to meet this need and attempted to differentiate species with restriction analysis of amplified products. However, as the primer system they used was developed originally for the study of fungal phylogenetics, it is questionable whether the system is also applicable to medically important fungi. In the present study a new PCR primer system was used that had broad detection capability with a primer pair based on conserved DNA sequences of 18S-rRNA genes of medically important fungi in the GenBank data base. This system was applied to blood specimens from a murine model of invasive candidosis and to clinical specimens from human patients. 
Table I. Fungal strains detected by PCR with the primer pair $\mathrm{B} 2 \mathrm{~F}$ and $\mathrm{B} 4 \mathrm{R}$

\begin{tabular}{|c|c|}
\hline Strain & $\begin{array}{l}\text { Number of } \\
\text { strains tested }\end{array}$ \\
\hline C. albicans serotype A & 4 \\
\hline C. albicans serotype B & 2 \\
\hline C. albicans var. stellatoidea & 2 \\
\hline C. tropicalis & 2 \\
\hline C. parapsilosis & 2 \\
\hline C. guilliermondii & 2 \\
\hline C. glabrata & 2 \\
\hline C. krusei & 2 \\
\hline C. kefyr & 2 \\
\hline H. anomala & 2 \\
\hline H. polymorpha & 1 \\
\hline S. cerevisiae & 2 \\
\hline Cr. neoformans & 3 \\
\hline$T$. beigelii & 3 \\
\hline M. furfur & 10 \\
\hline Pn. carinii & 1 \\
\hline A. fumigatus & 22 \\
\hline A. flavus & 2 \\
\hline A. niger & 2 \\
\hline A. nidulans & 2 \\
\hline A. oryzae & 1 \\
\hline A. terreus & 2 \\
\hline P. expansum & 1 \\
\hline$P$. citreo-viride & 1 \\
\hline P. commune & 1 \\
\hline$P$. notatum & 1 \\
\hline P. crustosum & 1 \\
\hline
\end{tabular}

\section{Materials and methods}

\section{Organisms}

The following strains were used in this study: $C$. albicans serotype A TIMM nos. 0239, 1623, 1768, 2726; C. albicans serotype B TIMM nos. 0170, 0172; C. albicans var. stellatoidea TIMM nos. 0310,$1308 ; C$. tropicalis TIMM nos. 1312, 0313; C. parapsilosis TIMM nos. 0288, 0292; C. guilliermondii TIMM nos. 0257, 0260; C. glabrata TIMM nos. 1062, 1064; $C$. krusei TIMM nos. 0269, 0270; C. kefyr TIMM nos. 0298, 0302; H. anomala JCM3585, \# 0018; H. polymorpha IFO1166; S. cerevisiae TIMM nos. 0925, 0927; $C r$. neoformans TIMM nos. 0354, 0362, 0372; $T$. beigelii TIMM nos. 1287, 1526, 1573; $M$. furfur TIMM nos. $1847,1848,1850,1851,1852,2462,2535,2681$, 2718,2782 ; A. fumigatus TIMM nos. 0063, 0064, 0068, $0078,0086,0090,0210,0108,0109,1335,1725,1732$, 1746, 1750, 1770, 1775, 1776, 1778, 1871, 3150, \#2021, \# 2022; A. flavus TIMM nos. 0057, 0059; A. niger TIMM nos. 0113,0114; $A$. nidulans TIMM nos. 0111, 2868 ; $A$. oryzae TIMM nos. $0117 ; A$. versicolor TIMM nos. 0121,$1290 ; A$. terreus TIMM nos. 0119,$0120 ; P$. expansum TIMM nos. $1293 ; P$, notatum TIMM nos. 0883; $P$. citreo-viride TIMM nos. $0882 ; P$. commune TIMM nos. $1331 ; P$. crustosum TIMM nos. 1332 ; Mucor circinelloides TIMM nos. 1324, 1325; Muc. racemosus TIMM nos. 1320 and Escherichia coli \# 529. Other genomic DNA samples provided by the following laboratories were also used: Pn. carinii from K. Kitada, Department of Tumor Biology, Institute of
Medical Science, University of Tokyo; methicillinresistant Staphylococcus aureus (MRSA) from $\mathrm{K}$. Ubukata, Department of Clinical Pathology, Teikyo University School of Medicine, Tokyo; calf thymus (Sigma); and human placenta from T. Sakamoto, Department of Obstetrics and Gynecology, Teikyo University School of Medicine.

\section{$D N A$ preparation from fungal cells}

All fungal strains were grown in or on YMPG broth or agar (yeast extract $0.3 \% \mathrm{w} / \mathrm{v}$, malt extract $0.3 \%$ $\mathrm{w} / \mathrm{v}$, peptone $0.5 \% \mathrm{w} / \mathrm{v}$, glucose $1 \%$, with or without agar $1.5 \% \mathrm{w} / \mathrm{v}$ ) at $27^{\circ}$ or $37^{\circ} \mathrm{C}$ for $1-2$ days.

Small scale extraction of genomic DNA from yeastlike fungi was performed as described by Philippsen $e t$ $a .^{25}$

For rapid extraction of DNA from yeast-like fungi, a small amount of the yeast colony was suspended in $100 \mu 1$ of lysis buffer ( $100 \mathrm{~mm}$ Tris- $\mathrm{HCl}, \mathrm{pH} 7 \cdot 5$, SDS $0.5 \% \mathrm{w} / \mathrm{v}, 30 \mathrm{~mm}$ EDTA). After vortex mixing for $5 \mathrm{~s}$, this mixture was incubated at $100^{\circ} \mathrm{C}$ for $15 \mathrm{~min} ; 100 \mu \mathrm{l}$ of $2.5 \mathrm{M}$ potassium acetate was added and it was mixed again, incubated on ice for $60 \mathrm{~min}$, centrifuged at $12000 \mathrm{rpm}$ for $5 \mathrm{~min}$ and the supernate was transferred to a new tube. DNA was precipitated with an equal volume of isopropanol, washed with $0.5 \mathrm{ml}$ of ethanol $99 \%$, dried and resuspended in $100 \mu \mathrm{l}$ of distilled water. The PCR template was $2 \mu \mathrm{l}$ of this DNA solution.

Small scale extraction of DNA from filamentous fungi was performed as described by Bainbridge $e t$ $a l^{26}$ and rapid extraction as described by Cenis. ${ }^{27}$

$E$. coli genomic DNA was extracted as described by Sambrook et al. ${ }^{28}$

\section{Oligonucleotide design}

The design of oligonucleotides used in this study was based on comparison of the sequences of $18 \mathrm{~S}$ (16S-like) ribosomal RNA genes (rDNA) in the GenBank data base (accession nos: M60302, $C$. albicans; M60308, C. tropicalis; M60307, C. parapsilosis; M60304, C. guilliermondii; M60311, C.glabrata; M60305, C. krusei; M60303, C. kefyr; M60306, C. lusitaniae; M60310, H. polymorpha; V01335, S. cerevisiae; M55625, Cr. neoformans; X12708, Pn. carinii; M55626, A. fumigatus; M55628, P. notatum; M55624, Blastomyces dermatitidis; M55627, Coccidioides immitis; X54863, Muc. racemosus; M24996, E. coli; M10098, Homo sapiens). The highly conserved sequences of the medically important fungi, but not of $M u c$. racemosus, $E$. coli or $H$. sapiens were analysed with the PC/GENE (Intelligenetics Inc., Genofit. SA, USA, kindly loaned by Teijin Co., Ltd, Yokohama, Japan) and two oligonucleotide primers-B2F: $5^{\prime}$-ACTTTCGATGGTAGGATAG-3' and B4R: $5^{\prime}$-TGATCGTCTTCGATCCCCTA-3' - made by Genosis Biotechnologies Inc., Texas, USA. The primers were expected to amplify a fragment of $687 \mathrm{bp}$ within the 18S-rDNA. Also, one oligonucleotide probe 18SIN3: 
A

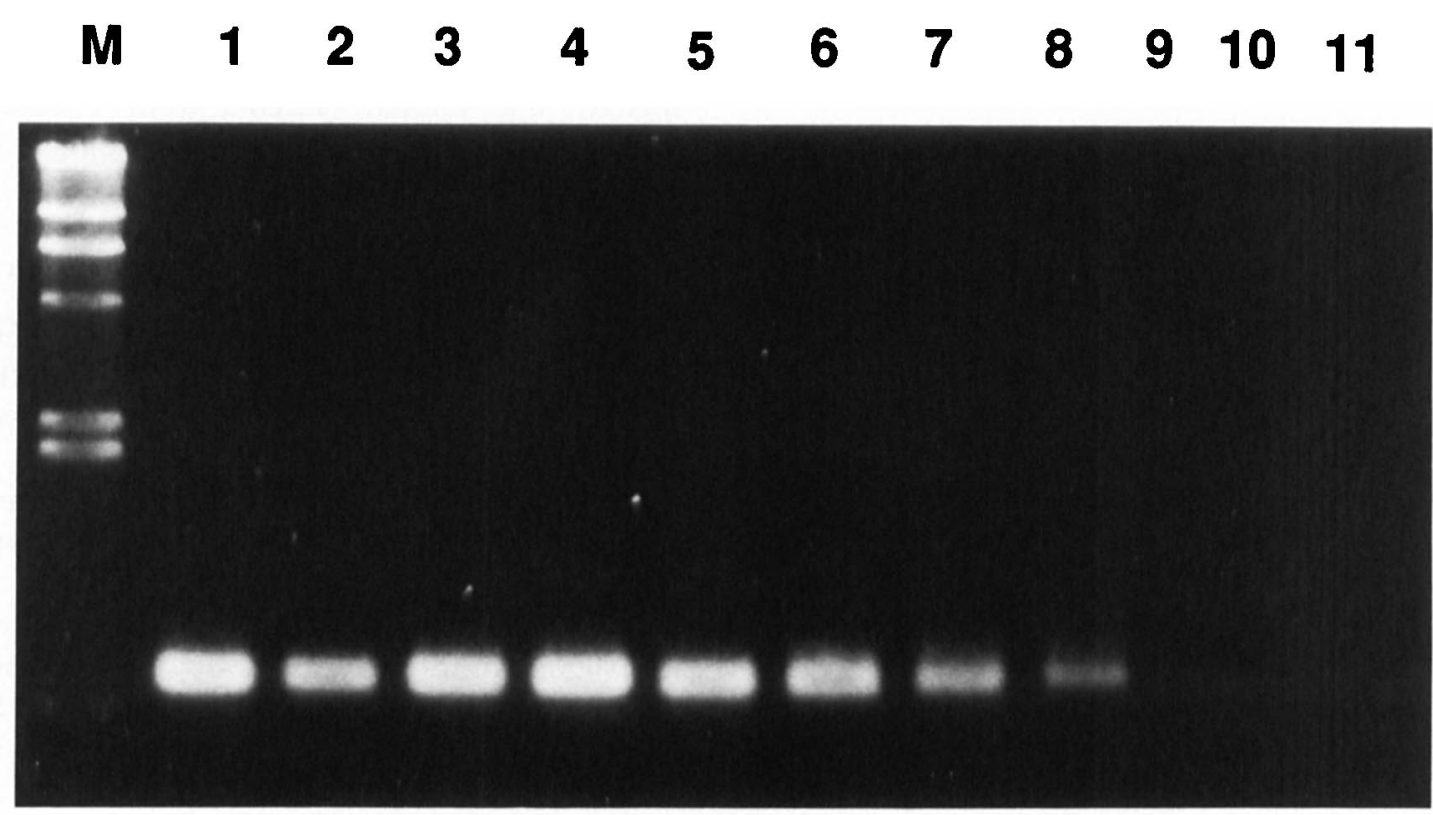

B

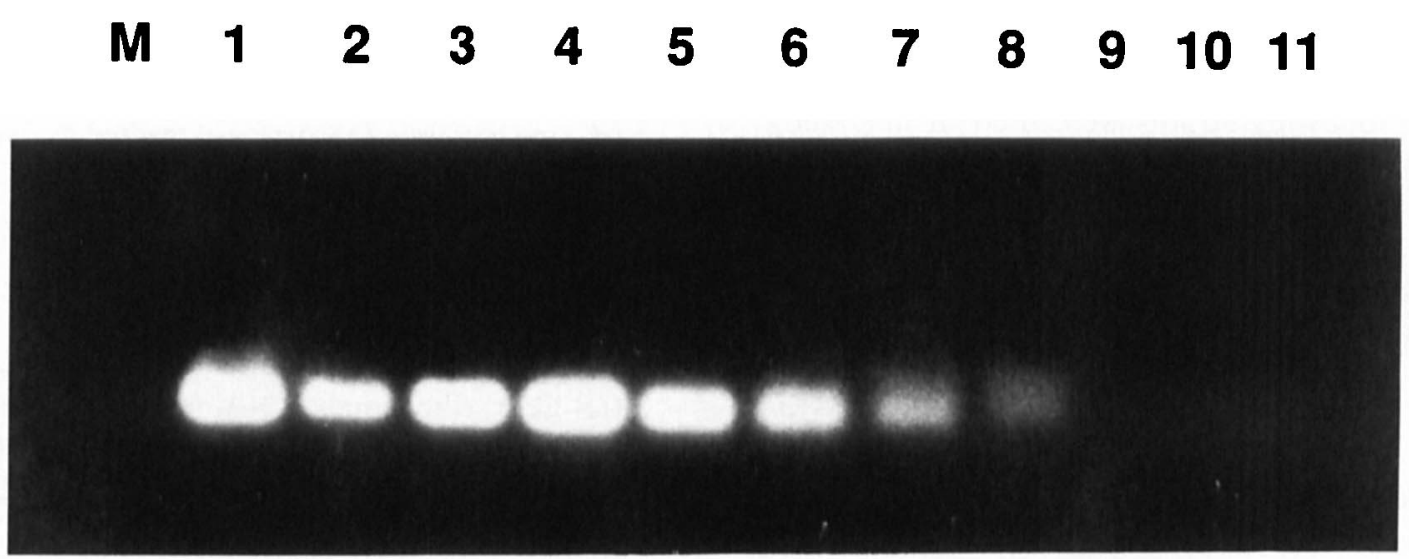

Fig. 1. Specificity of the PCR with primer pair B2F and B4R. Agarose 1.2\% gel electrophoresis of PCR products amplified from 10 ng of genomic DNA templates from various organisms was done. A, stained by ethidium bromide and visualised by UV irradiation; $\mathbf{B}$, followed by the chemiluminescence method of Southern analysis detected by Polaroid 612, ISO 20000 film. Lanes: M, HindIII-digested lambda DNA; 1, A. fumigatus TIMM3150; 2, A. flavus TIMM0057; 3, A. niger TIMM0113; 4, P. commune TIMM1331; 5, C. albicans TIMM1768; 6, C. parapsilosis TIMM0292; 7, C. tropicalis TIMM0313; 8, Cr. neoformans TIMM0354; 9, Muc. circinelloides TIMM1324; 10, E. coli; 11, human.

5'-CTGAGAAACGGCTACCACAT-3'. an internal region within the amplified products, was made for Southern hybridisation.

\section{$P C R$}

Each PCR assay contained $10 \mu \mathrm{l}$ of $10 \times$ reaction buffer [600 mM Tris- $\mathrm{HCl}, \mathrm{pH} 8 \cdot 5,150 \mathrm{~mm}\left(\mathrm{NH}_{4}\right)_{2} \mathrm{SO}_{4}$, $15 \mathrm{mM} \mathrm{MgCl}_{2}$ ], $100 \mu \mathrm{M}$ each of dATP, dCTP, dGTP and dTTP (Pharmacia, Uppsala, Sweden), 2.5 U of
Taq polymerase (Pharmacia), $30 \mathrm{pmol}$ of each primer and DNA template solution. The volume was made up to $100 \mu \mathrm{l}$ with distilled water. Each mixture was heated to $94^{\circ} \mathrm{C}$ for $5 \mathrm{~min}$ and $\mathrm{PCR}$ was performed under the following conditions: $94^{\circ} \mathrm{C}$ for $1 \mathrm{~min} ; 55^{\circ} \mathrm{C}$ for $2 \mathrm{~min}$ and $72^{\circ} \mathrm{C}$ for $3 \mathrm{~min} ; 30$ cycles. Thermal cycles were terminated by polymerisation at $72^{\circ} \mathrm{C}$ for $10 \mathrm{~min}$.

To examine the specificity of this system, the samples of genomic DNA extracted from the organisms were tested to see whether the primer pair amplified the 
A

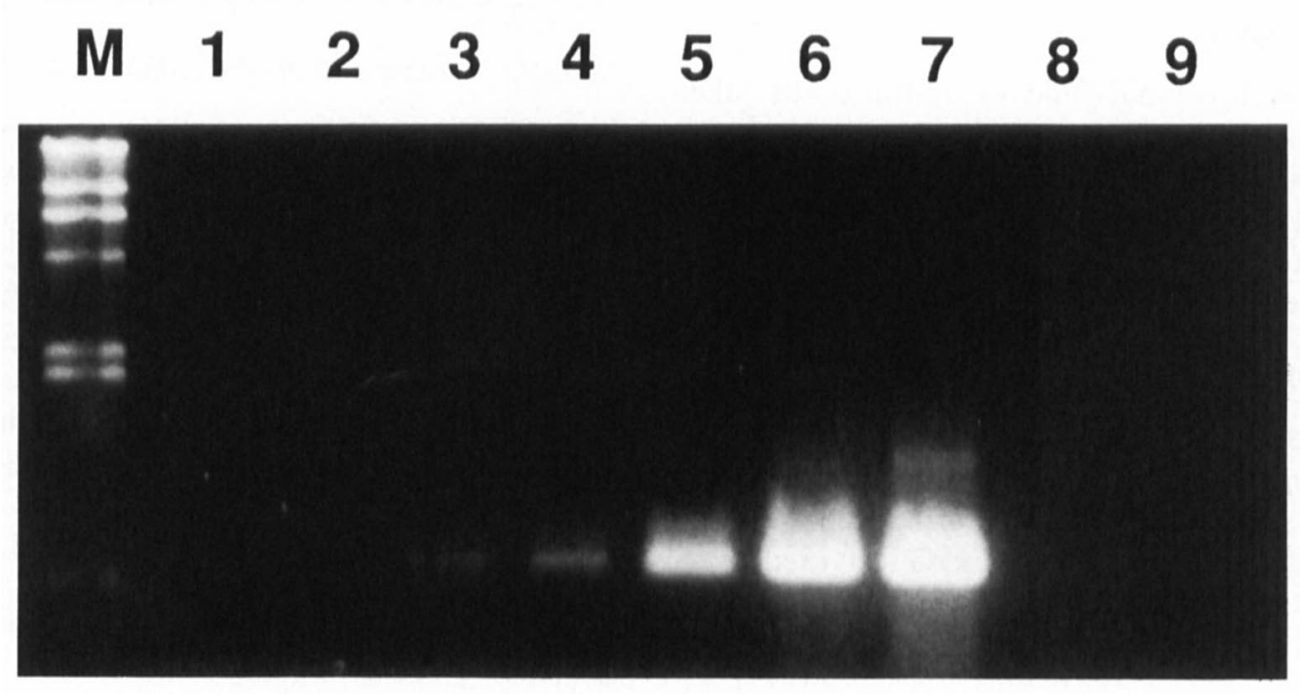

B

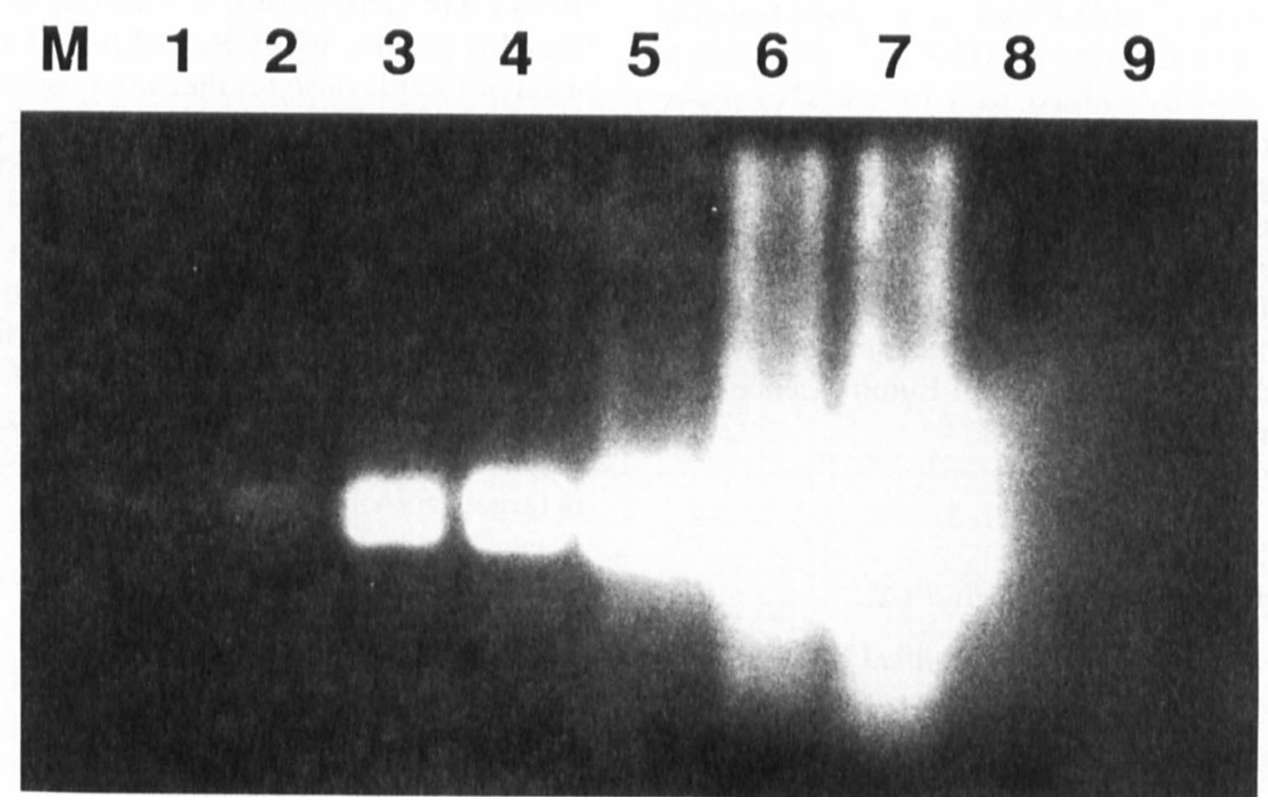

Fig. 2. Sensitivity of the PCR with primer pair B2F and B4R. Agarose $1.2 \%$ gel electrophoresis of PCR products amplified from different amounts of $C$. albicans, E. coli and human genomic DNA template was done. A, stained by ethidium bromide and visualised by UV irradiation; B, detection by chemiluminescence; detected by Polaroid 612, ISO 20000 film. Lanes: M, HindIII-digested lambda DNA; 1-7, $0,100 \mathrm{fg}, 1 \mathrm{pg}, 10 \mathrm{pg}, 100 \mathrm{pg}, 1 \mathrm{ng}, 10 \mathrm{ng}$ of $C$. albicans TIMM2726 DNA;8,10 ng of E. coli genomic DNA;9, $10 \mathrm{ng}$ of human genomic DNA.

same length of DNA products; $10 \mathrm{ng}$ of template DNA was used per reaction and Southern blot analysis was done for confirmation of the results.

To determine the lower limit of detection by PCR with the primer pair $\mathrm{B} 2 \mathrm{~F}$ and $\mathrm{B} 4 \mathrm{R}$, assays were performed with the genomic DNA of $C$. albicans TIMM2726 serially diluted to give a concentration range of $100 \mathrm{fg}-10 \mathrm{ng}$. Fungal DNA solutions, which were extracted as described by Buchman et al. ${ }^{11}$ from $100 \mu \mathrm{l}$ of normal human blood containing EDTA plus $10,10^{1}, 10^{2}, 10^{3}$ or $10^{4}$ cells of $C$. albicans TIMM1768, were also tested by PCR and Southern blot analysis.

\section{Infection of mice with C. albicans}

On day 0 , eight of 10 female ICR mice (5 weeks old; obtained from Nippon Bio-Supp. Center, Tokyo, Japan) were given $10^{6}$ cells of $C$. albicans TIMM1768 by intravenous injection in $200 \mu \mathrm{l}$ of sterile saline. Two mice were killed 1-4 days after inoculation, dissected and blood samples were taken from the hearts, to which $5 \mu \mathrm{l}$ of $0.5 \mathrm{~m}$ EDTA was added. From each blood sample, $50 \mu \mathrm{l}$ was cultured on YMPG agar incubated at $37^{\circ} \mathrm{C}$ for 2 days. Remaining blood samples were stored immediately at $-80^{\circ} \mathrm{C}$ until needed. DNA was extracted from $100 \mu \mathrm{l}$ of the blood 
sample from each mouse as described by Buchman et al. ${ }^{11}$

\section{Clinical specimens}

Blood, cerebrospinal fluid or sputum was taken from immunocompromised patients with fever who did not respond to any antibacterial chemotherapy and $100-\mu 1$ volumes of the samples were stored at $-80^{\circ} \mathrm{C}$ until needed. DNA extraction was performed as described by Buchman et al. ${ }^{11}$

\section{Serodiagnostic tests}

Cand-Tec 4 (Ramco, Houston); Pastorex Aspergillus $^{5}$ (Diagnostics Pastorex, Paris); Serodirect Eiken Cryptococcus $^{5}$ (Eiken Kagaku Corp., 1-33-8 Hongo, Bunkyo-ku, Tokyo 113 Japan) and $G$ test $^{6}$ (Seikagaku Corp., 2-1-5 Hashimoto-cho, Nihonbashi, Chuo-ku, Tokyo 103 Japan) were used as shown in table III.

\section{Agarose gel electrophoresis and Southern analysis}

PCR product $(5-10 \mu \mathrm{l})$ was electrophoresed in agarose $1.2 \%$ gel and visualised by staining with ethidium bromide. The DNA was transferred from the gels on to nylon membranes (Hybond $\mathrm{N}+$; Amersham), and then hybridised with the 18SIN3 probe labelled with a chemiluminescence detection system (ECL 3'-oligolabelling and detection system; Amersham). The membranes were washed according to the manufacturer's instructions and exposed to ISO 20000 instant film (Polaroid 612 film; Polaroid, Cambridge, USA) for $1 \mathrm{~s}-30 \mathrm{~min}$ in the camera luminometer system (Camlight 501; Analytical Luminescence Laboratory, San Diego, CA, USA).

\section{Results}

\section{Specificity of detection of fungi by $P C R$}

A product of $c .700 \mathrm{bp}$ was amplified by PCR from all 78 strains of 25 medically important fungal species tested (table I), but not from Muc. circinelloides, $M u c$. racemosus, E. coli, MRSA, calf thymus or human placenta. No amplification was observed without templates. Fig. 1A shows PCR products amplified from eight different fungi, but not from $M u c$. circinel-

Table II. Murine model of $C$. albicans infections

\begin{tabular}{ccccc}
\hline $\begin{array}{c}\text { Days after } \\
\text { infection }\end{array}$ & $\begin{array}{c}\text { Mouse } \\
\text { no. }\end{array}$ & PCR & Culture & $\begin{array}{c}\text { Kidney } \\
\text { abscess }\end{array}$ \\
\hline $0^{*}$ & 1 & - & - & - \\
1 & 2 & - & - & - \\
2 & 3 & + & + & - \\
3 & 4 & + & - & - \\
& 5 & - & - & + \\
4 & 6 & + & - & + \\
& 7 & + & - & + \\
& 8 & - & - & + \\
& 9 & + & - & +
\end{tabular}

*Not infected. loides, E. coli or man. No differences in length were found among any of the species. This specificity was subsequently confirmed by Southern analysis (fig. 1B).

\section{Sensitivity of detection of $C$. albicans by PCR}

PCR with the primer pair B2F and B4R was able to detect 1 pg of $C$. albicans genomic DNA with ethidium bromide staining (fig. 2A) and $100 \mathrm{fg}$ by chemiluminescence (fig. 2B). This sensitivity is equivalent to the detection of one-to-two yeast cells. ${ }^{24}$ PCR with the template extracted from blood samples containing $C$. albicans cells detected $10^{2}$ C. albicans cells by ethidium bromide staining and 10 cells by Southern analysis (data not shown). There was no amplified product from blood without $C$. albicans cells and there was no cross-hybridisation to the probe 18SIN3.

\section{Detection of fungal-specific DNA in blood specimens} from mice infected with $C$. albicans

A summary of the PCR and culture results and the presence of kidney abscesses is given in table II. Only one sample on day two after infection (mouse no. 3) showed a positive culture. The culture-positive sample was also positive by PCR, and five of seven culturenegative samples also resulted in a positive PCR result. In every mouse from day two to day four, multiple foci of kidney abscesses were observed. Since the intensities of PCR products from culture-negative samples were as strong as those from culture-positive samples and the results of PCR, culture and detection of kidney abscesses were all negative in uninfected mice, this does not appear to be an indication of false positive results. All PCR products led to amplification of single fragments $c$. $700 \mathrm{bp}$ in length, and they were confirmed as target DNA by Southern analysis.

\section{Detection of fungal-specific DNA from clinical specimens}

A summary of the results of PCR, culture and diagnostic kits is given in table III. The samples from patients 1, 2 and 3 were culture-positive: $C$. albicans from blood; $H$. anomala from cerebrospinal fluid and $A$. fumigatus from sputum, respectively; all of them gave positive results in the PCR. Samples from patients no. 4 were PCR positive; the blood culture was negative, but CSF was culture positive for $\mathrm{Cr}$. neoformans. Blood samples from patients 5,6 and 7 (immunocompromised hosts who were resistant to anti-bacterial antibiotics) gave negative results in culture, but two of the three were positive in the PCR. Each amplified DNA fragment revealed a single band of $c .700 \mathrm{bp}$ and these bands were confirmed as target DNA by Southern analysis.

\section{Discussion}

The results of this study demonstrated firstly that the 18S-rDNA-based PCR method had high sensitivity and specificity for a wide range of medically important 
Table III. Detection of pathogenic fungi in clinical samples by PCR with the primer pair B2F and B4R

\begin{tabular}{|c|c|c|c|c|c|}
\hline Patient no. & $\begin{array}{l}\text { Specimen used } \\
\text { for PCR }\end{array}$ & $\begin{array}{l}\text { PCR } \\
\text { results }\end{array}$ & Culture & $\begin{array}{l}\text { Diagnostic kit } \\
\quad \text { (result) }\end{array}$ & Clinical diagnosis \\
\hline 1 & Blood & + & $\begin{array}{c}\text { C. albicans } \\
\text { Blood }(+)\end{array}$ & Cand-Tec $(-)^{*}$ & Diabetes mellitus \\
\hline 2 & CSF & + & $\begin{array}{l}H, \text { anomala } \\
\text { Blood }(+), \operatorname{CSF}(+)\end{array}$ & Not tested & Meningitis \\
\hline 3 & Sputum & + & $\begin{array}{l}\text { A. fumigatus } \\
\operatorname{Sputum}(+)\end{array}$ & Pastorex Aspergillus $(-)^{*}$ & Aspergilloma \\
\hline 4 & Blood & + & $\begin{array}{l}\text { Cr. neoformans } \\
\text { Blood }(-), \operatorname{CSF}(+)\end{array}$ & $\begin{array}{l}\text { Serodirect Eiken Cryptococcus } \\
\operatorname{Serum}(+), \operatorname{CSF}(+) \\
\text { G-test }(+)^{*}\end{array}$ & $\begin{array}{l}\text { Cryptococcosis } \\
\text { (meningitis, pneumonia) }\end{array}$ \\
\hline 5 & Blood & + & - & Cand-Tec $(-)^{*}$, G-test $(-)^{*}$ & Malignant lymphoma \\
\hline 6 & Blood & + & - & Cand-Tec $(-)^{*}$, G-test $(-)^{*}$ & Acute lymphocytic leukaemia \\
\hline 7 & Blood & - & - & Cand-tec $(-)^{*}$ & Chronic renal failure \\
\hline
\end{tabular}

CSF, cerebrospinal fluids.

*Serum was used as a sample.

fungi. Secondly, the capability of this technique to identify these fungi from the blood of an animal model and clinical specimens of blood, cerebrospinal fluid and sputum make it useful for clinical diagnosis.

The sensitivity of this PCR system with the primer pair B2F and B4R, with both purified DNA and yeast cells contained in blood reached a detection level as high as that of the previously reported PCR method for pathogenic fungi, ${ }^{11-15,23}$ when purified DNA or cultured cells of $C$. albicans were used as the templates. There are only three reports ${ }^{11,12,15}$ referring to the sensitivity of PCR with artificial samples containing body fluids and the lower limit was the same as that reported here: 10-100 cells or cfu prepared from blood or urine. Moreover, from the results of the animal model and clinical specimens, PCR was shown to be more sensitive than culture methods with $0.1 \mathrm{ml}$ of blood samples. This may be explained by the loss of viability of fungi contained in blood, but $>10^{2}$ cells are estimated to exist in $0.1 \mathrm{ml}$ of blood if calculated as DNA. In this sensitivity study, two kinds of PCR templates were used, the purified DNA solution and crude DNA extracts from blood containing $C$. albicans cells. Assuming that one $C$. albicans cell contains c. $37 \mathrm{fg}$ of DNA, ${ }^{29}$ Buchman's method of fungal DNA preparation from clinical samples including blood may be highly efficient.

DNA sequences of 18S-rDNA of various organisms have been deposited in the GenBank data base for purposes of phylogenetic study. ${ }^{24,30,31}$ Our primer pair, B2F and B4R, was designed in conserved sequences of 18S-rDNA to be specific only for medically important fungi and this specificity was achieved. For example, there have been numerous reported cases of systemic infection with $M$. furfur ${ }^{22}$ and this was detected successfully by the PCR system although the organism cannot be detected by a conventional culture system. Pn. carinii (which was recently demonstrated to be a fungus) ${ }^{32}$ was also detected by this PCR system. Some reports of detection of Pn. carinii with PCR have been published. ${ }^{16-20}$ Lipschik et al.$^{16}$ reported the PCR diagnosis of $P n$. carinii infection based on 18S-rDNA different from that used here. Their primer pair was designed to have species-specificity as reported by many others. ${ }^{11-15,17,20}$ Diagnostic kits also reveal less sensitivity on tested samples than by our technique.

New technology, such as enzymic detection of PCR products $^{33}$ and the non-radioisotopic method of Southern analysis as demonstrated in this study, make PCR applicable to the routine laboratory diagnosis of infections by medically important fungi. Further evaluation of this PCR method with other clinical specimens is underway.

We thank K. Kitada, University of Tokyo, K. Ubukata and T. Sakamoto, Teikyo University School of Medicine, for providing DNA, M. Mitsuya and K. Wada, Department of Microbiology and Immunology, Teikyo University School of Medicine, for serodiagnostic kit analysis; and K. Uchida, Research Center for Medical Mycology, Teikyo University, for providing fungal strains. We also thank the various hospital colleagues who supplied us with clinical specimens.

\section{References}

1. Anaissie E, Bodey GP, Kantarjian $\mathrm{H}$ et al. New spectrum of fungal infections in patients with cancer. Rev Infect Dis $1989 ; 11$ : 369-378.

2. Komshian SV, Uwaydah AK, Sobel JD, Crane LR. Fungemia caused by Candida species and Torulopsis glabrata in the hospitalized patient: frequency, characteristics, and evaluation of factors influencing outcome. Rev Infect Dis 1989 ; 11: $379-390$.

3. Meunier F, Aoun M, Bitar N. Candidemia in immunocompromised patients. Clin Infect Dis 1992; 14 Suppl 1: S120-S125.

4. Kohno S, Mitsutake K, Maesaki S et al. An evaluation of

serodiagnostic tests in patients with candidemia: betaglucan, mannan, Candida antigen by Cand-Tec and Darabinitol. Microbiol Immunol 1993; 37: 207-212.

5. Buckley HR, Richardson MD, Evans EGV, Wheat LJ. Immunodiagnosis of invasive fungal infection. $\mathrm{J} \mathrm{Med} \mathrm{Vet} \mathrm{Mycol}$ 1992; 30 Suppl $1: 249-260$.

6. Obayashi T, Yoshida M, Tamura H, Aketagawa J, Tanaka S, Kawai T. Determination of plasma $(1 \rightarrow 3)$-beta-D-glucan: a new diagnostic aid to deep mycosis. J Med Vet $M y c o l$ 1992; 30: 275-280.

7. Gabal MA. Development of a chromosomal DNA probe for the laboratory diagnosis of aspergillosis. Mycopathologia 1989; 106: 121-129.

8. Holmes AR, Lee YC, Cannon RD, Jenkinson HF, Shepherd 
MG. Yeast-specific DNA probes and their application for the detection of Candida albicans. $J$ Med Microbiol 1992; 37: 346-351.

9. Stockman L, Clark KA, Hunt JM, Roberts GD. Evaluation of commercially available acridinium ester-labeled chemiluminescent DNA probes for culture identification of Blastomyces dermatitidis, Coccidioides immitis, Cryptococcus neoformans, and Histoplasma capsulatum. J Clin Microbiol 1993; 31 : 845-850.

10. Saiki RK, Scharf S, Faloona F et al. Enzymatic amplification of $\beta$-globin genomic sequences and restriction site analysis for diagnosis of sickle cell anemia. Science $1985 ; 230$ : 1350 1354.

11. Buchman TG, Rossier M, Merz WG, Charache P. Detection of surgical pathogens by in vitro DNA amplification. Part I. Rapid identification of Candida albicans by in vitro amplification of a fungus-specific gene. Surgery 1990; 108: 338-347.

12. Miyakawa Y, Mabuchi T, Kagaya K, Fukazawa Y. Isolation and characterization of a species-specific DNA fragment for detection of Candida albicans by polymerase chain reaction. J Clin Microbiol 1992; 30: 894-900.

13. Spreadbury C, Holden D, Aufauvre-Brown A. Bainbridge B, Cohen J. Detection of Aspergillus fumigatus by polymerase chain reaction. J Clin Microbiol 1993; 31: 615-621.

14. Murayama SY. cDNA cloning of Candida albicans aspartic proteinase and its diagnostic application. In: Maresca B, Kobayashi GS, Yamaguchi $\mathrm{H}$ (eds) Molecular biology and its application to medical mycology. Berlin, SpringerVerlag. 1993: 149-158.

15. Oren I, Manavathu EK, Lerner SA. Isolation of a speciesspecific DNA fragment for the rapid detection of Candida albicans by polymerase chain reaction (PCR). 91st meeting of the American Society for Microbiology 1991, Dallas; Abstract D46.

16. Lipschik GY, Gill VJ, Lundgren JD et al. Improved diagnosis of Pneumocystis carinii infection by polymerase chain reaction on induced sputum and blood. Lancet $1992 ; 340$ : 203-206.

17. Kitada K, Oka S, Kimura S et al. Detection of Pneumocystis carinii sequences by polymerase chain reaction: anima models and clinical application to noninvasive specimens. $J$ Clin Microbiol 1991; 29: 1985-1990.

18. Wakefield AE, Pixley FJ, Banerji $\mathrm{S}$ et al. Detection of Pneumocystis carinii with DNA amplification. Lancet $1990 ; 336$ : 451-453.

19. Schluger N, Sepkowitz K, Armstrong D et al. Detection of
Pneumocystis carinii in serum of AIDS patients with Pneumocystis pneumonia by the polymerase chain reaction. J Protozool 1991; 38: 240S-242S.

20. Olsson M, Elvin K, Löfdahl S, Linder E. Detection of Pneumocystis carinii DNA in sputum and bronchoalveolar lavage samples by polymerase chain reaction. J Clin Microbiol 1993; 31: 221-226.

21. Klein AS, Tortora GT, Malowitz R, Greene WH. Hansenula anomala: A new fungal pathogen: two case reports and a review of the literature. Arch Intern Med 1988; 148: $1210-1213$.

22. Ingham E, Cunningham, AC. Malassezia furfur. J Med Vet Mycol 1993; 31: 265-288.

23. 'Hopfer RL, Walden P, Setterquist S, Highsmith WE. Detection and differentiation of fungi in clinical specimens using polymerase chain reaction (PCR) amplification and restriction enzyme analysis. $J$ Med Vet Mycol 1993; 31: 65-75.

24. Innis MA, Gelfand DH, Sninsky JJ, White TJ (eds). PCR protocols: a guide to methods and applications. San Diego, Academic Press Inc. 1990.

25. Philippsen P, Stotz A, Scherf C. DNA of Saccharomyces cerevisiae. Methods Enzymol 1991; 194: 169-182.

26. Bainbridge BW, Spreadbury CL, Scalise FG, Cohen J. Improved methods for the preparation of high molecular weight DNA from large and small scale cultures of filamentous fungi. FEMS Microbiol Lett 1990; 66: 113118.

27. Cenis JL. Rapid extraction of fungal DNA for PCR amplification. Nucleic Acids Res 1992; 20: 2380.

28. Sambrook J, Fritsch EF, Maniatis T. Molecular cloning: a laboratory manual, 2nd edn. Cold Spring Harbor, NY, Cold Spring Harbor Laboratory Press. 1989.

29. Riggsby WS, Torres-Bauza LJ, Wills JW, Townes TM. DNA content, kinetic complexity, and the ploidy question in Candida albicans. Mol Cell Biol 1982; 2: 853-862.

30. Bowman BH, Taylor JW, White TJ. Molecular evolution of the fungi: human pathogens. Mol Biol Evol 1992; 9: 893-904.

31. Wainright PO, Hinkle G, Sogin ML, Stickel SK. Monophyletic origins of the metazoa: an evolutionary link with fungi. Science $1993 ; 260$ : 340-342.

32. Edman JC, Kovacs JA, Masur H, Santi DV, Elwood HJ, Sogin ML. Ribosomal RNA sequence shows Pneumocystis carinii to be a member of the fungi. Nature $1988 ; 334: 519-522$.

33. Ubukata K, Nakagami S, Nitta A et al. Rapid detection of the $m e c A$ gene in methicillin-resistant staphylococci by enzymatic detection of polymerase chain reaction products. $J$ Clin Microbiol 1992; 30: 1728-1733. 